\section{Bad blood}

\section{An inquiry has begun into the infection of thousands of people with haemophilia in the United Kingdom who contracted hepatitis and HIV in the 1970s and 1980s. Rebecca Coombes reports}

\section{What's the story}

An independent inquiry into how thousands of UK people with haemophilia came to be infected with contaminated blood in the 1970s and 1980s opened last week. The opening was rather dramatically marked by allegations aired on the BBC that UK doctors ignored warnings that could have prevented these patients becoming infected with HIV and hepatitis C. Several patients also claimed that they were unknowingly placed in trials to test the infectivity of blood products, were secretly tested for HIV infection, and were not informed of positive results until years later in some cases.

The story has been unfolding for decades. In the 1970 s and 1980 s in the United Kingdom 4670 patients with haemophilia were exposed to hepatitis C through contaminated NHS blood and blood products, and of this group 1243 were also exposed to HIV. So far 1757 of these patients have died, and many more are now terminally ill. Haemophilia, the condition in which one of the clotting proteins in blood (most commonly factor VIII) is either missing or insufficient, is treated by injection of the missing protein. The protein can now be created through recombinant technology. But in the period when the infections occurred it was derived from the pooled plasma of many thousands of donors. So, if any of the sources were infected with a bloodborne virus, the whole batch would be contaminated. During this time large amounts of the clotting agent factor VIII were imported from the United States, where commercial suppliers paid high risk donors (widely called "skid row donors"), such as prisoners, for their blood.

\section{Who's saying what?}

Successive UK governments have refused to hold a public inquiry, saying that politicians, civil servants, and doctors did not know of the dangers of factor VIII in time for its use to be stopped. This assertion was disputed by several of the patients and relatives giving their account of what happened at the independent inquiry in Westminster last week.

One, Robert Mackie, said: "They are saying they didn't know about the AIDS virus. I'm sorry, but by June 1983 the European commissioners put out a warning that all haemophiliacs in Europe were to be informed of the risks of AIDS. Why weren't we warned of the risks?"

Carol Grayson told how her late husband,

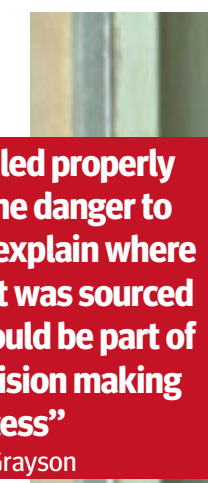

Peter, was given blood contaminated with $\mathrm{HIV}$ and hepatitis $\mathrm{C}$. He was given diagnoses of HIV in 1985 and hepatitis C in 1994, and he died in 2005, at the age of 47. Mrs Grayson told the hearing that doctors "failed properly to explain the danger to patients and explain where the treatment was sourced so patients could be part of the joint decision making process." She drew comparisons with the Tuskegee syphilis scandal in the US, in which some patients were not told they had syphilis so that doctors could monitor the progression of the disease.

\section{What has the media coverage been like?}

To coincide with the opening of the inquiry in Westminster, the BBC current affairs television programme Newsnight ran a special film last week, which used official documents that have only recently resurfaced after being "lost" for decades to back up claims that UK doctors, scientists, civil servants, and politicians were aware of the threats to patients but failed to

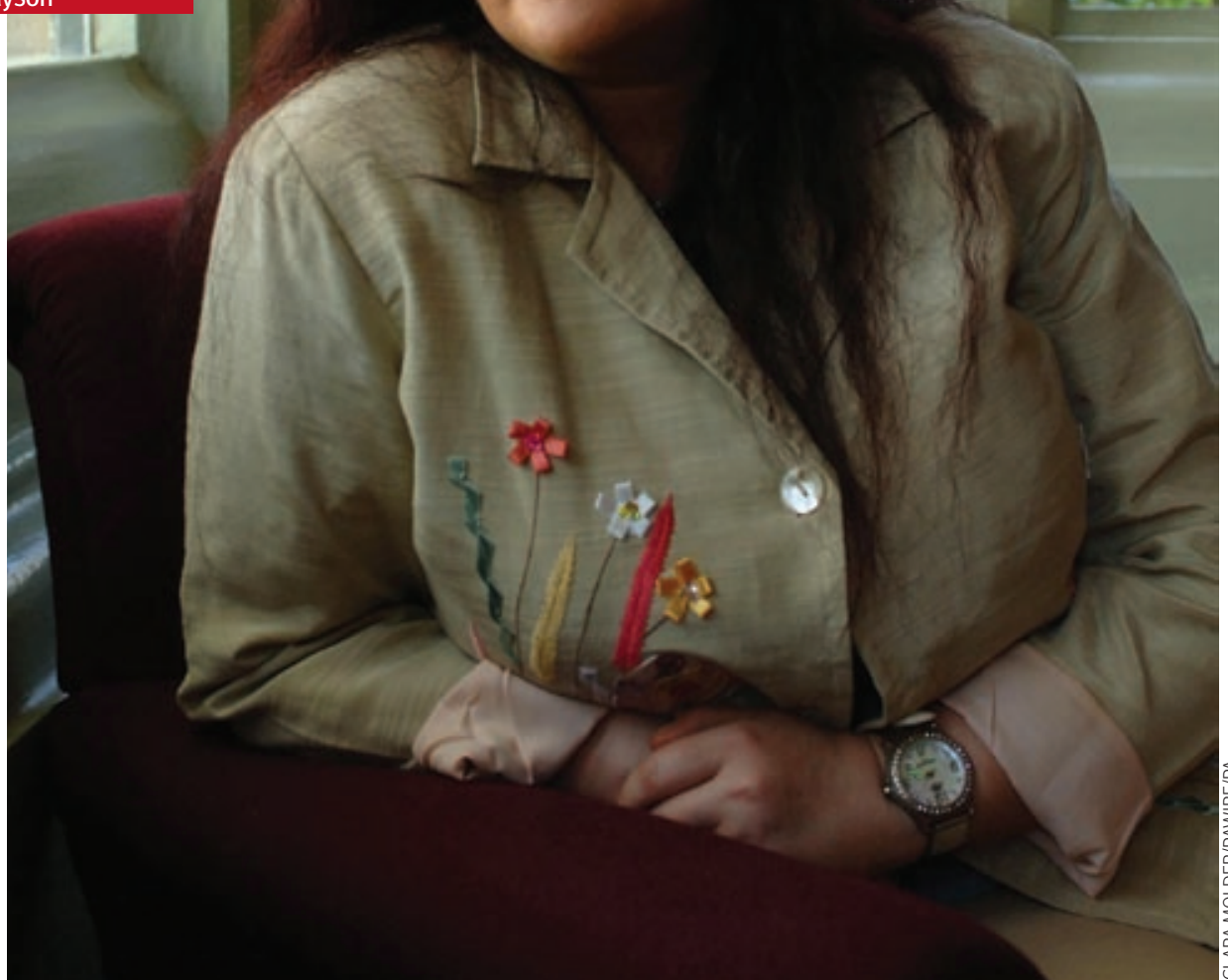




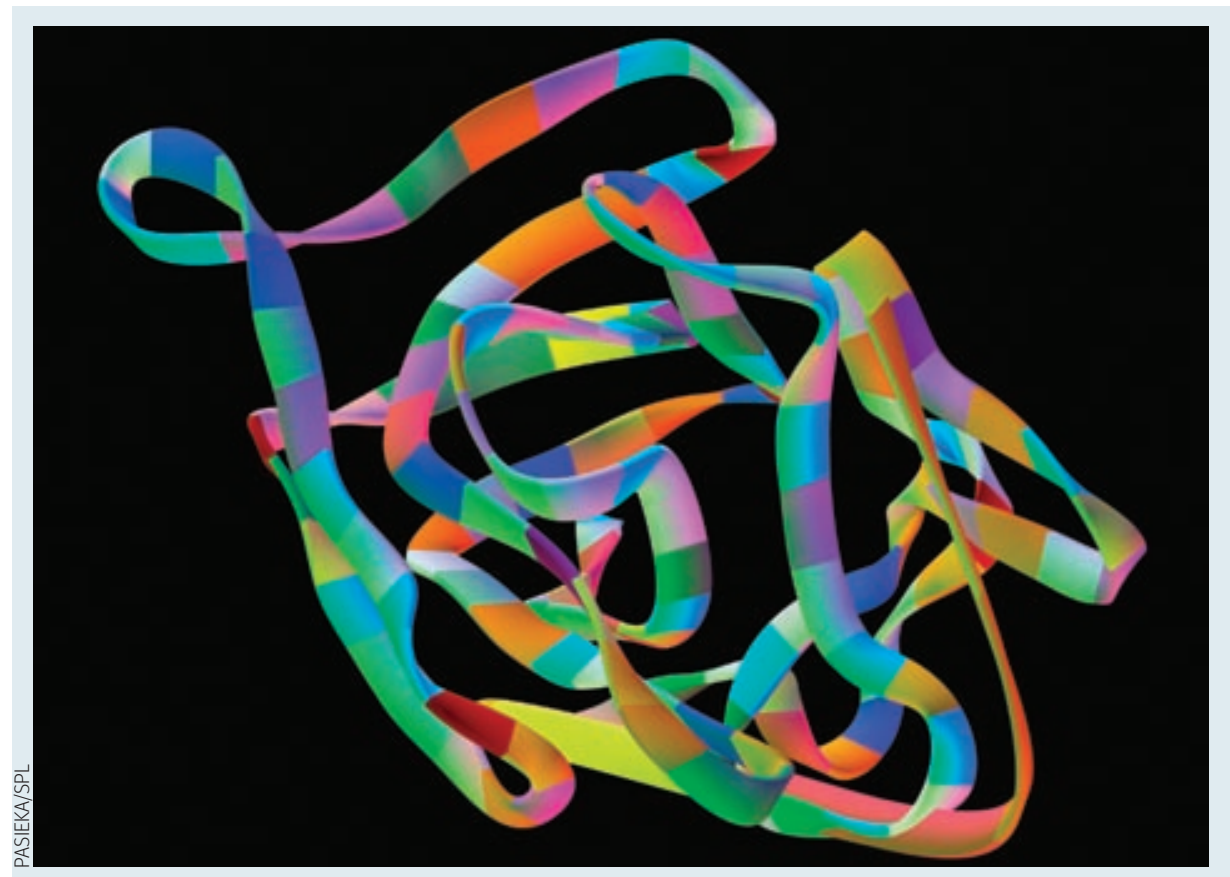

Computer molecular model of the clotting agent factor VIII

\section{TIMELINE: FACTOR VIII, HEPATITIS, AND HIV}

1966 The first blood clotting products for haemophiliacs are produced. The first commercial factor VIII concentrate is produced by Baxter's Hyland division

1970s Britain imports huge quantities of factor VIII from the US (BMJ1998;316:489-90)

1974 The World Health Organization warns Britain not to import blood from countries with a high prevalence of hepatitis, such as the United States

1976 A drive to invest in making the UK self sufficient in blood products begins, but the initiative is not followed through

1982 First UK patient with haemophilia to be given diagnosis of AIDS

1983 US Food and Drug Administration regulations for the collection of plasma exclude donors from high risk groups

MAY Dr N Galbraith of the Public Health Laboratory Service writes to Dr lan

1983 Field of the health department: "I have reviewed the literature and come to the conclusion that all blood products made from blood donated in the USA after 1978 should be withdrawn from use until the risk of AIDS transmission by these products has been clarified." Nevertheless, a health department letter the same month concludes that the suggestion "is premature in relation to the evidence and unbalanced in that it does not take into account the risks to haemophiliacs of withdrawing a major source of their factor VIII supplies." No restrictions are placed on imported concentrates, except on those for children under the age of 4 years and for people with mild haemophilia

APRIL A number of people with haemophilia begin a civil action against the

1989 health department

(Source: Tainted Blood (www.taintedblood.info)) stop transfusions http://news.bbc.co.uk/1 hi/programmes/newsnight/default.stm).

The documents were obtained by relatives of some of the people who have died. Of greatest note was a letter from the head of the UK's public health surveillance centre warning the health department about the risk of HIV infection from factor VIII after Britain's first case in Cardiff. The letter, dated May 1983-before most haemophiliac patients became infected with HIV-says that all US blood products made from donations after 1978 should be banned. However, the health department continued to allow imports to be used, saying that the risks were outweighed by the need to keep people with haemophilia supplied with factor VIII.

The UK had a desperate shortage of factor VIII. Despite calls from the World Health Organization in the mid-1970s for countries to be self sufficient in blood products, all UK efforts failed dismally, because of underfunding and lack of political will.

Documents released last week by a group called Tainted Blood www.taintedblood. info, made up of relatives of deceased patients, show that fears about blood products being infected with hepatitis $\mathrm{C}$ were circulating as early as 1976 and that similar fears about HIV were around by 1982 . The Neresnight programme questioned scientists' and doctors' motives in keeping quiet about the risks of imported blood products. It pointed to one official document that reflected the need to find "virgin haemophiliacs," those who hadn't already received any possibly contaminated blood products from abroad. These patients would be very valuable in testing the infectivity of newer, heat treated products, which had just come on the market and were supposed to be safer.

\section{What happens next?}

The new inquiry will investigate the circumstances surrounding the supply of contaminated blood to patients. Although not an official public inquiry, it has considerable weight. Chaired by a member of the House of Lords and former solicitor general, the inquiry sits in the Palace of Westminster and, for the next four months, will hold public hearings in which evidence will be provided by civil servants, patients, and politicians, among others. www.archercbbp.com). Lord Morris of Manchester, credited with getting the inquiry off the ground, said that the inquiry "seemed the only way to restore public confidence in the safety of blood supplies and Whitehall's ability to react to new viruses." Rebecca Coombes journalist, London rcoombes@bmjgroup.com 


\section{ATLANTIC CROSSING Uwe E Reinhardt}

\section{Single-payer systems spark endless debate}

\section{Are they a panacea or a form of "socialised medicine"? Americans just cannot agree}

Whenever Americans lapse into their periodic "conversations" on health reform, a single-payer health system is proposed by some as the panacea and condemned by others as "socialised medicine." Rarely are the pros and cons of single-payer systems fairly debated.

In single-payer health systems, the entire population shares one health insurance carrier, usually the central or provincial government. Such systems should not be confused with "socialised medicine," in which the government also owns and operates the healthcare delivery system. Singlepayer health systems typically are just social insurance grafted onto pluralistic delivery systems, which may include investor owned, for-profit enterprises. Canada's and Taiwan's health systems are classic examples of this genre, as is the government run Medicare system for elderly people in the United States for the services it covers.

To their proponents, single-payer health systems offer several distinct advantages over pluralistic health insurance systems, such the American system. Firstly, single-payer systems are the ideal vehicle for implementing an egalitarian social ethic, if that is what the citizenry desires. Such systems can apply the same terms of healthcare delivery to all of its citizens, regardless of the patient's socioeconomic status, including styles of rationing and the fees paid for given treatments. It is not so in the US. The Medicaid programme for the poor run by state governments, for example, pays physicians and hospitals significantly lower feessometimes less than half-than those paid for commercially insured patients. These differential prices signal to providers that the social value of health care depends, in the eyes of legislators, on the recipient's wealth or insurance status. Many American physicians predictably and rationally respond to that signal by refusing to treat Medicaid patients altogether.

Secondly, single-payer systems are administratively simple. They typically spend only a fraction of what pluralistic health insurance systems spend on administrative overheads, leaving more of national healthcare spending for health care proper. One reason these systems spend less on administration is that they are the ideal platform for a coherent electronic information infrastructure, with a commonly shared nomenclature.

In Taiwan's single-payer system, for example, utilisation trends and healthcare spending can be tracked electronically almost in real time. By contrast, in the United States, paper based claims processing is still common among the myriad of private health insurers, and total national health spending can be roughly estimated only with a lag of a year or more. Furthermore, claims processing in the US engages armies of costly intermediaries who translate nomenclature used by providers into the differing nomenclatures used by third party payers, who help patients claim reimbursements from insurance carriers, who help physicians bill private insurers, and who help insurers defend themselves against over-billing by providers. In a recent article entitled "Billing Battle: Fights Over Health Claims Spawn a New Arms Race," the Wall Street Journal (14 February 2007) reported that American insurers and physicians were spending billions of dollars fighting over insurance claims, and that some consulting firms now earned handsome profits by helping both sides in this arms race with customised software.

The built-in pitfalls of singlepayer systems, however, must be acknowledged as well.

Firstly, single-payer systems allocate disproportionate market power to the buy side of health care, which allows government to keep prices at the minimum necessary to keep providers in the system. Providers understandably may question the

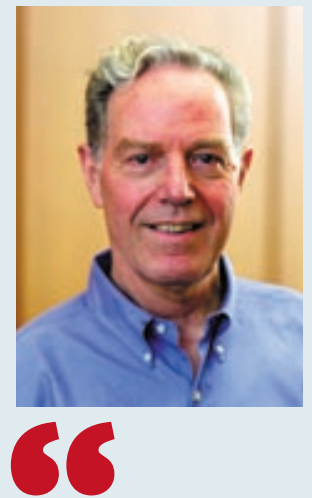

Single-payer systems have poor political prospects in countries that hold sacred the right of individuals to jump queues with their money

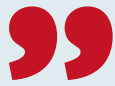

fairness of so asymmetric a distribution of market power in a health system. To be sure, the low prices it forces on the system allow society to provide more real health care for a given budget than could be delivered in a more expensive pluralistic system, and it also makes universal health insurance coverage more affordable. On the other hand, the extremely low profit margins it yields the provider of health care makes single-payer systems less hospitable to innovation in healthcare products and services and in the organisation of healthcare delivery, areas in which the US excels, sometimes to excess.

Secondly, in single-payer systems spending on health care is pitted against other government priorities and easily falls victim to the politician's perennial desire to campaign on tax cuts. The barebones technology, physical amenities, and queues that unduly low global budgets in singlepayer systems tend to beget inevitably trigger political forces for turning the system over to allegedly "more efficient” private market forces. Canada is in the midst of a debate on this issue.

Single-payer systems have poor political prospects in countries that hold sacred the right of individuals to jump queues with their money, all the more so if the distribution of family income is highly unequal. That is certainly so in the United States where, it seems, it is considered ever more acceptable for moneyed elites to purchase for themselves superior access to prestigious private schools and universities, a higher quality healthcare experience, superior access to the political process, and even superior justice.

Uwe E Reinhardt is James Madison professor of political economy, Princeton University, Princeton, NJ, United States reinhard@princeton.edu

The author wishes to thank Tsung-mei Cheng, author of “Taiwan's New National Health Insurance Program: Genesis and Experience So Far" (Health Affairs May/June 2003;22:61-76) for her valuable contributions to this column. 